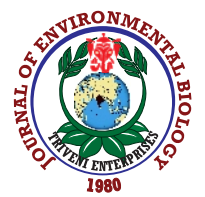

\title{
Effect of deficit irrigation on yield and water productivity of sunflower in East and South-eastern coastal plains of Odisha
}

\author{
P.K. Sahu' ${ }^{1 *}$ A.P. Sahu', P.S. Brahmanand ${ }^{2}$, B. Panigrahi', D.M. Das ${ }^{3}$, B.C. Sahoo and D.K. Swain ${ }^{4}$ \\ 'SWCE, College of Agricultural Engineering and Technology, O.U.A.T, Bhubaneswar-751 003, India \\ ${ }^{2}$ Agronomy, Indian Institute of Water Management, Bhubaneswar-751 023, India \\ ${ }^{3}$ Agricultural Engineering, Krishi Vigyan Kendra, Gajapati-761 016, India \\ ${ }^{4} \mathrm{ASM}$, Indian Institute of Technology, Kharagpur-721 302, India \\ *Corresponding Author Email : pramit.sahu17@gmail.com
}

\section{Abstract}

Aim: To study the effect of deficit irrigation on yield and water productivity of sunflower in East and South eastern coastal plains of Odisha.

Methodology: The present study on water productivity was undertaken using hybrid sunflower (Swathi: NSFH-145) with application of deficit irrigation having Management Allowable Deficit level of 20\%, 40\%, 60\% and one farmers' practice of $70 \%$ MAD level of irrigation. Growth attributes like leaf area Index, plant height, and head diameter were recorded at 20, 45, 65 and 80 days after sowing. Yield attributes like 1000 seed weight (test weight), above ground biomass and grain yield, were recorded after threshing.

Results: The growth, yield and water productivity of sunflower were significantly influenced by different irrigation levels. Irrigation scheduling at $20 \%$ MAD level showed the highest grain yield, while the lowest yield was obtained from the farmers' practice. Irrigation at $60 \%$ MAD level showed the highest water productivity when compared with farmer's practice as it produced the highest yield per unit quantity of water application of $0.85 \mathrm{~kg} \mathrm{~m}^{-3}$ and also produced the highest average benefit to cost ratio of 2.08 .

Interpretation: Taking the yield, water productivity and benefit-cost ratio into account, irrigation at $60 \%$ MAD level was found to be the best. However, irrigation at $50 \%$ to $60 \% \mathrm{MAD}$ level may be suggested for growing sunflower under water scarce conditions in sandy loam soil for increasing water productivity.

Key words: Deficit irrigation, Maximum allowable depletion, Sunflower, Water productivity

How to cite : Sahu, P.K., A.P. Sahu, P.S. Brahmanand, B. Panigrahi, D.M. Das, B.C. Sahoo and D.K. Swain: Effect of deficit irrigation on yield and water productivity of sunflower in East and South-eastern coastal plains of Odisha. J. Environ. Biol., 42, 1062-1069 (2021).
Experimental plot design (Randomised Block Design)

Applying deficit irrigation (20\%, 40\%, $60 \%$ and $70 \%$ MAD levels)

Collection of crop yield and growth attributes under deficit irrigation

Data analysis and estimation of water productivity

Irrigation scheduling at 60\% MAD level has shown maximum water productivity of sunflower 


\section{Introduction}

Agriculture plays an important role in sustenance of livelihood and food security of human population on the earth. There are various factors which influence the metabolism of plants, changing the processes of growth and development of plants as well as increasing their resistance to stress factors (Vladimir et al., 2020). But fresh water is an essential and the most critical input for sustainable agricultural production and productivity (Mila et al., 2017). However, the increasing water scarcity is a major constraint in fulfilling the irrigation water demands of Indian agriculture (Das et al., 2018). Irrigation is the largest consumer of water compared to other sectors; however, the share of water for irrigation is expected to decrease by 10 to $15 \%$ in near future due to shrinking water resources (Geerts and Raes, 2009; Panigrahi, 2011). In arid and semi-arid regions, water scarcity is the main yield limiting factor that restricts application of irrigation water to meet the complete crop water requirements. Therefore, it is very important to determine the ways to maintain optimum crop yield with higher water productivity under water scarce situation. Irrigation water requirement models of major crops developed by the researchers can help to ascertain the irrigation requirement of crops which will help in irrigation planning, especially under water scarce conditions (Panigrahi et al., 1992; Elsheikh, 2015).

Application of regulated deficit irrigation strategies is one of the most promising methods for improving irrigation water productivity (Qureshi et al., 2015). Efficient irrigation system can help to achieve benefit from irrigation scheduling through sustainable water management by adopting deficit irrigation techniques with proper irrigation scheduling. The deficit irrigation technique reduces seepage, percolation and evapotranspiration, which leads to increase in water productivity compared to traditional practices (Kaviya et al., 2018). However, studies on water saving technologies in sunflower production systems mainly focus on the innovations in cultivation systems that incorporate furrow irrigation with deficit irrigation concepts which give some inspiring records of water saving for sunflower cultivation.

Oilseed plays an important role in the Indian agricultural economy next to food grains in terms of area, production, import and export. The oilseed accounts for $13 \%$ of the gross cropped area, $3 \%$ of the gross national product and $10 \%$ value of all agricultural commodities (NMOOP, 2018). Sunflower (Helianthus annuus L.) is cultivated predominantly as source of oil and vegetable protein (Awady et al., 2017), and it is considered as a major oil seed crop in the world because it contains about $85-90 \%$ unsaturated fatty acids (Flagella et al., 2002; Vega and Hall, 2002), high oil content and around $14 \%$ protein content (Bajehbaj, 2010). It is also one of the most promising oil seed crop having moderate tolerance to soil salinity (Li et al., 2020). It is cultivated in 0.34 million ha area in India, with annual production of 0.24 million tons at the productivity level of $699 \mathrm{~kg} \mathrm{ha}^{-1}$ (Agricultural Research Data Book, 2018). In Odisha, sunflower is grown in 0.02 million ha area with production and productivity of 0.12 million tons and 1100 $\mathrm{kg} \mathrm{ha}^{-1}$, respectively. It has the potential to replace high water requirement crops like rice during Rabi season in Odisha. Moreover, sunflower as an oil seed crop offers good opportunity for diversification of cereal based cropping system of the state during Rabi season and can enhance the profitability of farmers. The need of the hour is to enhance the seed yield and water productivity of sunflower from the present level (Singh and Singh, 2002). Sunflower crop is highly sensitive to water stress from flowering to grain filling stage (Singh et al., 2007). Therefore, it is considered as an indicator plant for moisture stress experiments (Howell et al., 2015). The yield of sunflower is highly influenced by irrigation management, particularly at critical stages of growth and, therefore proper irrigation scheduling can produce the potential yield. Hybrid sunflower responds relatively better to management factors, especially irrigation, than local sunflower varieties (Albaji et al., 2011). The efficient irrigation management practices in hybrid sunflower not only save water but also take care of irregular and erratic distribution of rainfall and produces a credible yield. Hence, it becomes imperative to investigate different irrigation management options in sunflower to increase the production per unit of water application by efficiently utilizing the available water resources.

Though, sunflower can sustain moisture stress conditions but its response to yield variation needs to be studied (Ghani et al., 2000). Reports on the evaluation of sunflower yield with deficit irrigation practices in India and as well as in Odisha is meagre. Therefore, more field experiments should be carried out in various agro-climatic conditions of the country to identify and suggest the most suitable irrigation schedule in sunflower to increase yield and water productivity compared to traditional practices. This can be of great use to the policy makers, agricultural officers and sunflower growing farmers of the state and thus, can increase yield and water productivity of sunflower. Keeping in view the above facts, this study was undertaken to assess the crop growth and yield attributes of sunflower under different deficit irrigation levels and to evaluate the water productivity of sunflower under deficitirrigation practices.

\section{Materials and Methods}

Experimental site: The research work was undertaken for two consecutive years during the rabi season of 2017-2018 and 20182019 at the experimental field of Precision Farming Development Centre, Odisha University of Agriculture and Technology (OUAT), Bhubaneswar, (India). The study site is located at $21^{\circ} 16^{\prime} \mathrm{N}$ latitude and $85^{\circ} 47^{\prime} \mathrm{E}$ longitude and $30 \mathrm{~m}$ above mean sea level. The area is situated in East and South-eastern coastal plain agroclimatic zone of Odisha (Fig. 1). The climate of the study area is classified as sub-humid and sub tropical in nature. The average annual rainfall is about $1450 \mathrm{~mm}$, out of which about $80 \%$ is received during the monsoon season. For the study, different meteorological data of the experimental area during the study period were collected on daily basis from the meteorological observatory of OUAT. 
Table 1: Physico-chemical properties of soil

\begin{tabular}{|c|c|c|c|c|}
\hline \multirow[t]{2}{*}{ Soil parameters } & & \multicolumn{3}{|c|}{ Soil depth range } \\
\hline & & $0-20 \mathrm{~cm}$ & $20-40 \mathrm{~cm}$ & $40-60 \mathrm{~cm}$ \\
\hline \multirow[t]{3}{*}{ Soil texture } & Sand $\%$ & 69.8 & 68.6 & 67.7 \\
\hline & Silt $\%$ & 21.6 & 22.2 & 22.4 \\
\hline & Clay \% & 8.6 & 9.2 & 9.9 \\
\hline Bulk density $\left(\mathrm{g} \mathrm{cm}^{-3}\right)$ & & 1.51 & 1.55 & 1.57 \\
\hline Average field infiltration rate $\left(\mathrm{mm} \mathrm{hr}^{-1}\right)$ & & & 10.4 & \\
\hline $\mathrm{pH}$ & & 4.7 & 4.81 & 5.2 \\
\hline$E C\left(d s m^{-1}\right)$ & & 0.09 & 0.08 & 0.08 \\
\hline Organic carbon $(\%)$ & & 0.45 & 0.42 & 0.49 \\
\hline Nitrogen $\left(\mathrm{kg} \mathrm{ha}^{-1}\right)$ & & 118 & & \\
\hline Phosphorus (kg ha ${ }^{-1}$ ) & & 19 & & \\
\hline Potassium (kg ha $\left.{ }^{-1}\right)$ & & 98 & & \\
\hline
\end{tabular}

Soil characteristics: The soil at the experimental site was sandy loam and taxonomically grouped under the order Alfisol. Soil samples from three depths $0-20,20-40$ and $40-60 \mathrm{~cm}$ were analyzed for physico-chemical properties of the root zone soil layers. The soil type was sandy loam with average bulk density and average infiltration rate of $1.54 \mathrm{~g} \mathrm{~cm}^{-3}$ and $10.4 \mathrm{~mm} \mathrm{hr}^{-1}$, respectively. The physico-chemical characteristics of soil of the experimental site are shown in Table 1.

Experimental details and field layout: The experiment was laid out in a randomized block design with 4 treatments and 5 replications. Twenty plots measuring $20 \mathrm{~m}^{2}$ were laid in the field. Bund height of $200 \mathrm{~mm}$ was maintained around the treatment plots and irrigation channels were made around each plot. Sunflower seeds (variety-NSFH-145) were sown @ $3 \mathrm{~kg} \mathrm{ha}^{-1}$ at a depth of $5 \mathrm{~cm}$. The row to row and plant to plant spacing was 45 $\mathrm{cm}$ and $30 \mathrm{~cm}$, respectively. A digital moisture meter was properly calibrated before taking soil moisture measurement. Daily soil moisture readings were taken at a depth of $20 \mathrm{~cm}$ and $35 \mathrm{~cm}$. Field capacity and permanent wilting point of the experimental site were estimated using pressure plate apparatus, which was found to be $18 \%$ and $8 \%$ on volume basis. Recommended fertiliser dose of N:P:K of 40:60:20 kg ha' was applied to each treatment. The treatments of the experiment were designed for three levels of deficit irrigation based on the percentage of maximum allowable depletion (MAD) of available soil water (ASW). These treatments were compared with irrigation practice followed by local farmers. One farmers practice (FP) treatment with average MAD level of $70 \%$ ASW was taken by collecting information from sunflower growing farmers of the agro-climatic zone. The treatments details of the experiment are described as follows: $\mathrm{T}_{1}$ : Irrigation at $20 \%$ MAD of ASW; $\mathrm{T}_{2}$ : Irrigation at $40 \%$

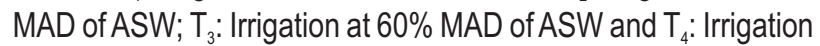
at $70 \%$ MAD of ASW (FP).

Growth and yield attributes: In order to evaluate the effect of different levels of moisture regimes on crop responses, data on growth and yield attributes of sunflower crop were collected and analyzed from the treatment plots. These data were also necessary for estimating water productivity and selecting the best irrigation schedule. Growth parameters such as plant height, head diameter and leaf area index (LAI) were recorded at 20, 45, 65 and 80 days after sowing (DAS). To study the important growth parameters of sunflower, five plants from net plot area of the experiment were selected randomly and tagged for recording observations at different growth stages starting from sowing to harvesting as per the methodology provided by Haq et al. (2006) and Nasim et al. (2012). The yield attributes such as grain yield, 1000 test weight and above ground biomass was recorded after threshing and the obtained data were statistically analyzed for variance (Basa et al., 2014). Post-harvest data pertaining to grain yield was measured on the day before general harvest.

Estimation of water productivity: Water productivity is an indicator of effective use of irrigation water for crop production. Water productivity was determined in terms of irrigation water productivity and total water productivity (Panigrahi, 2013).

$$
\text { Irrigation water productivity }\left(\mathrm{kg} \mathrm{m}^{-3}\right)=\frac{\text { Seed yield }\left(\mathrm{kg} \mathrm{ha}^{-1}\right)}{\text { Total irrigation applied }\left(\mathrm{m}^{3} \mathrm{ha}^{-1}\right)}
$$

$$
\text { Total water productivity }\left(\mathrm{kg} \mathrm{m}^{-3}\right)=\frac{\text { Yield }\left(\mathrm{kg} \mathrm{ha}^{-1}\right)}{\text { Total water used }\left(\mathrm{m}^{3} \mathrm{ha}^{-1}\right)}
$$

$$
\text { Net water productivity }\left(\text { Rs m }^{-3}\right)=\frac{\text { Net return }\left(\text { Rs ha }^{-1}\right)}{\text { Total water used }\left(\mathrm{m}^{3} \text { ha }^{-1}\right)}
$$

Statistical analyses: Data collected from the field experiment was statistically analyzed for ANOVA as per Gomez and Gomez (1984). Significant and non-significant variables were tested by Duncan's Multiple Range Test(DMRT) at $5 \%$ probability level. 


\section{Results and Discussion}

The growth of sunflower in terms of plant height was different under various treatments. The sunflower height increases up to the mid-season stage and then the plant height became stable. The plant height of sunflower at 80 DAS was highest at 20\% MAD level i.e., $123.6 \mathrm{~cm}$ and $120.4 \mathrm{~cm}$ during 2017-18 and 2018-19, respectively, which was found statistically superior to other stress irrigation levels (Table 2). In general, the plant height exhibited a declining trend with the increase in moisture stress from irrigation at $20 \%$ MAD to $70 \%$ MAD, the average plant height of sunflower of both the years declined by $18.3 \%$ when it was subjected to extreme moisture stress i.e. irrigation at $70 \%$ MAD level (FP). This might be due to slow metabolic rate in terms of photosynthesis and nitrogen metabolism when plants are subjected to moisture stress. (Gholamhoseini etal., 2013; Wahba et al., 1990).

Similarly, other growth parameters like leaf area index (LAl) and above ground biomass of sunflower were also noticed to be superior when higher proportion of irrigation was provided during both the years (Table 2). LAl represents the spread of plant leaf that intercept the sun and high LAI represents high potential for photosynthesis. It ranged from 1.7 under irrigation at $60 \%$ MAD level to 1.9 under irrigation at 20\% MAD level during 201718 which was found statistically significant. As water became limiting factor for basic physiological processes, statistically significant variation in LAl was observed among the levels of deficit irrigation. The study depicted that the root zone moisture stress due to deficit irrigation had significant effect on growth and canopy of sunflower. Due to lower canopy spread, the chances of evaporation from the soil surface increases and transpiration rate decreases which leads to lower water productivity of applied irrigation However, the treatment differences were not statistically significant during 2018-19. Similar relationship between irrigation and growth of sunflower was reported by Jing et al. (2020). In general, the above ground biomass was positively correlated with moisture availability and plants exhibited decrease in above ground biomass when subjected to higher extent of moisture stress. As a result of higher plant height and LAl when irrigation was provided at $20 \%$ MAD, the above ground biomass of sunflower was found to be superior (5316.4 $\mathrm{kg} \mathrm{ha}^{-1}$ and $5290.8 \mathrm{~kg} \mathrm{ha}^{-1}$ during 2017-18 and 2018-19).

The superiority of above ground biomass when irrigation was given at $20 \%$ MAD was found statistically significant to all other treatments during 2018-19. However, it was found on par with irrigation provided at $40 \%$ MAD during first year. The advancement of leaf senescence of due to moisture stress might have resulted in reduction in above ground biomass. This is in conformity with the findings of Langeroodi et al. (2014) who reported a decline in total dry matter by $50 \%$ when irrigation interval increased from 45 to $90 \%$ MAD. Overall, the results of two years of experiment revealed that the deficit irrigation had a significant response on vegetative growth and biomass accumulation in sunflower considering other factors as constant. The vegetative development of plant decreased as the root zone moisture stress increased, however, the relationship was not linear and with linear increase in moisture stress there was a nonlinear effect on sunflower growth attributes.

Table 2: Plant growth attributes of sunflower under different irrigation regimes for the year 2017-18 and 2018-19

\begin{tabular}{lllllll}
\hline Treatments & \multicolumn{2}{c}{ Plant height $(\mathbf{c m})$} & \multicolumn{2}{c}{ Leaf area index } & \multicolumn{2}{c}{ Above ground biomass $\left(\mathbf{k g ~ h a}{ }^{-1}\right)$} \\
\cline { 2 - 7 } & $\mathbf{2 0 1 7 - 1 8}$ & $\mathbf{2 0 1 8 - 1 9}$ & $\mathbf{2 0 1 7 - 1 8}$ & $\mathbf{2 0 1 8 - 1 9}$ & $\mathbf{2 0 1 7 - 1 8}$ & $\mathbf{2 0 1 8 - 1 9}$ \\
\hline $\mathrm{T}_{1}$ & 123.6 & 120.4 & 1.1 & 1.9 & 5316 & 5291 \\
$\mathrm{~T}_{2}$ & 117.4 & 114.8 & 1.9 & 1.9 & 5167 & 5072 \\
$\mathrm{~T}_{3}$ & 106.2 & 107.0 & 1.7 & 1.7 & 4766 & 4691 \\
$\mathrm{~T}_{4}$ & 98.7 & 100.6 & 1.7 & 1.7 & 4020 & 4129 \\
Sem $( \pm)$ & 0.6 & 0.7 & 0.1 & 0.1 & 49.7 & 45.1 \\
$\mathrm{CD}(5 \%)$ & 2.0 & 2.4 & 0.1 & 0.2 & 164.1 & 151.3 \\
\hline
\end{tabular}

Table 3: Yield attributes and yield of sunflower under different irrigation regimes

\begin{tabular}{lllllll}
\hline Treatments & \multicolumn{2}{c}{ Head diameter $(\mathbf{c m})$} & \multicolumn{2}{c}{ 1000 grain weight $(\mathbf{g})$} & \multicolumn{2}{c}{ Yield $(\mathbf{k g ~ h a})^{-1}$} \\
\cline { 2 - 7 } & $\mathbf{2 0 1 7 - 1 8}$ & $\mathbf{2 0 1 8 - 1 9}$ & $\mathbf{2 0 1 7 - 1 8}$ & $\mathbf{2 0 1 8 - 1 9}$ & $\mathbf{2 0 1 7 - 1 8}$ & $\mathbf{2 0 1 8 - 1 9}$ \\
\hline $\mathrm{T}_{1}$ & 23.6 & 23.1 & 53.8 & 54.0 & 1758 & 1709 \\
$\mathrm{~T}_{2}$ & 21.1 & 20.8 & 52.9 & 53.0 & 1678 & 1628 \\
$\mathrm{~T}_{3}$ & 20.6 & 20.3 & 51.6 & 51.7 & 1638 & 1585 \\
$\mathrm{~T}_{4}$ & 18.8 & 19.3 & 50.7 & 50.3 & 1005 & 987 \\
Sem $( \pm)$ & 0.6 & 0.6 & 0.8 & 0.5 & 31.6 & 32.1 \\
$\mathrm{CD}(5 \%)$ & 1.6 & 1.8 & 1.3 & 1.3 & 91.7 & 93.5 \\
\hline
\end{tabular}


Table 4: Water productivity of sunflower during 2017-2018

\begin{tabular}{|c|c|c|c|c|c|c|}
\hline Irrigation method & Treatments & $\begin{array}{l}\text { Irrigation } \\
\text { applied (mm) }\end{array}$ & $\begin{array}{l}\text { Total water } \\
\text { used }(\mathrm{mm})\end{array}$ & $\begin{array}{l}\text { Yield } \\
\left(\mathrm{kg} \mathrm{ha}^{-1}\right)\end{array}$ & $\begin{array}{l}\text { Irrigation water } \\
\text { productivity }\left(\mathrm{kg} \mathrm{m}^{-3}\right)\end{array}$ & $\begin{array}{l}\text { Total water } \\
\text { productivity }\left(\mathrm{kg} \mathrm{m}^{-3}\right)\end{array}$ \\
\hline \multirow[t]{4}{*}{ Furrow irrigation } & $\mathrm{T}_{1}$ & 195 & 230 & 1758 & 0.90 & 0.76 \\
\hline & $\mathrm{T}_{2}$ & 184 & 219 & 1678 & 0.91 & 0.77 \\
\hline & $\mathrm{T}_{3}$ & 166 & 201 & 1638 & 0.98 & 0.81 \\
\hline & $\mathrm{T}_{4}$ & 212 & 247 & 1005 & 0.47 & 0.41 \\
\hline
\end{tabular}

Table 5 : Water productivity of sunflower during 2018-2019

\begin{tabular}{lllllll}
\hline Irrigation method & Treatments & $\begin{array}{l}\text { Irrigation } \\
\text { applied }(\mathbf{m m})\end{array}$ & $\begin{array}{l}\text { Total water } \\
\text { used }(\mathbf{m m})\end{array}$ & $\begin{array}{l}\text { Yield } \\
\left(\mathbf{k g ~ h a} \mathbf{~}^{-1}\right)\end{array}$ & $\begin{array}{l}\text { Irrigation water } \\
\left.\text { productivity } \mathbf{~ ( k g ~ m ~}^{-3}\right)\end{array}$ & $\begin{array}{l}\text { Total water } \\
\text { productivity }\left(\mathbf{k g ~ ~ ^ { - 3 }}\right)\end{array}$ \\
\hline Furrow irrigation & $\mathrm{T}_{1}$ & 213 & 222 & 1709 & 0.79 & 0.75 \\
& $\mathrm{~T}_{2}$ & 206 & 215 & 1628 & 0.80 & 0.76 \\
& $\mathrm{~T}_{3}$ & 175 & 186 & 1585 & 0.91 & 0.85 \\
& $\mathrm{~T}_{4}$ & 221 & 230 & 987 & 0.45 & 0.43 \\
\hline
\end{tabular}

Table 6: Economic water productivity under different treatments

\begin{tabular}{lllll}
\hline Irrigation method & Irrigation levels & $\begin{array}{l}\text { Water used } \\
(\mathbf{m m})\end{array}$ & $\begin{array}{l}\text { Net return } \\
(\text { Rs.) }\end{array}$ & $\begin{array}{l}\text { Net economic water } \\
\text { productivity }\left(\text { Rs } \mathbf{m}^{-3}\right)\end{array}$ \\
\hline Furrow irrigation & $\mathrm{T}_{1}$ & 226 & 45,130 & 19.9 \\
& $\mathrm{~T}_{2}$ & 217 & 44,350 & 20.5 \\
& $\mathrm{~T}_{3}$ & 190 & 43,670 & 22.9 \\
& $\mathrm{~T}_{4}$ & 235 & 13,370 & 5.7 \\
\hline
\end{tabular}

$\mathrm{T}_{1}$ : Irrigation at $20 \% \mathrm{MAD}$ of $\mathrm{ASW} ; \mathrm{T}_{2}$ : Irrigation at $40 \% \mathrm{MAD}$ of $\mathrm{ASW} ; \mathrm{T}_{3}$ : Irrigation at $60 \% \mathrm{MAD}$ of $\mathrm{ASW}$ and $\mathrm{T}_{4}:$ Irrigation at $70 \% \mathrm{MAD}$ of $\mathrm{ASW}(\mathrm{FP})$

The yield attributes of sunflower like head diameter and test weight decreased progressively as moisture stress increased from 20\% MAD to 70\% MAD. The head diameter was highest (23.6 cm and $23.1 \mathrm{~cm}$ ) during 2017-18 and 2018-19, respectively when irrigation was provided at $20 \%$ MAD (Table 3). It might be due to assured maintenance of proper soil moisture status throughout the crop period. In case of farmers practice, head diameter was (18.84 cm and $19.26 \mathrm{~cm}$ ) during 2017-18 and 201819 , respectively. The lowest head diameter in $70 \%$ MAD may be attributed as non-maintenance of sufficient soil moisture (i.e., up to field capacity) during the crop critical periods. Smaller head diameter ultimately leads to less number of grains per head and finally reduces the total grain yield. On an average for two years, it reduced by $12.4 \%$ and $18.4 \%$ when irrigation was provided at $60 \%$ and $70 \%$ MAD (FP). Similarly, the test weight of 1000 grains of sunflower was found positively correlated with higher assurance of moisture through irrigation. The highest average 1000 grain weight of $53.8 \mathrm{~g}$ and $54.04 \mathrm{~g}$ was noticed under irrigation at 20\% MAD level during 2017-18 and 2018-19, respectively. In contrary, the lowest test weight of 1000 grains (50.7 $\mathrm{g}$ and $50.3 \mathrm{~g}$ ) during 2017-18 and 2018-19, was noticed with farmers' practice which indicates that root zone soil moisture dynamics caused unfavorable effect on the biomass content of seeds. However, the decline in test weight at $70 \%$ MAD level compared to $20 \%$ MAD level was only $6 \%$. This finding clearly reveal that the gap in test weight between the treatments irrigated at $70 \%$ MAD and $20 \%$ MAD was very low as compared to the volume of irrigation applied to the treatments. Garcia-Lopez et al. (2016) reported the percentage of irrigation supply for sunflower crop should range between $60 \%$ and $80 \%$ of the optimal (defined by the irrigation schedule that avoids water stress throughout the crop cycle), for the semi-arid conditions of Southern Spain, which would enable farmers to save water for other crops with higher water productivity. However, for a sub-tropical and sub-humid climate like Eastern India 20\% maximum allowable soil moisture depletion is optimal for growing sunflower.

The seed yield of sunflower exhibited positive correlation with higher proportion of available moisture content which is in contrary with the findings of Howell et al. (2015) who reported the stability of seed yield of sunflower in both drought and normal conditions under semi-arid climate (Table 3). Statistical analysis revealed a significant difference in yield among the treatments which depicts a good crop response to irrigation schedule at different MAD levels. The highest yield of $1816 \mathrm{~kg} \mathrm{ha}^{-1}$ and 1700 $\mathrm{kg} \mathrm{ha}^{-1}$ was recorded in 20\% MAD levels of irrigation during 2017- 


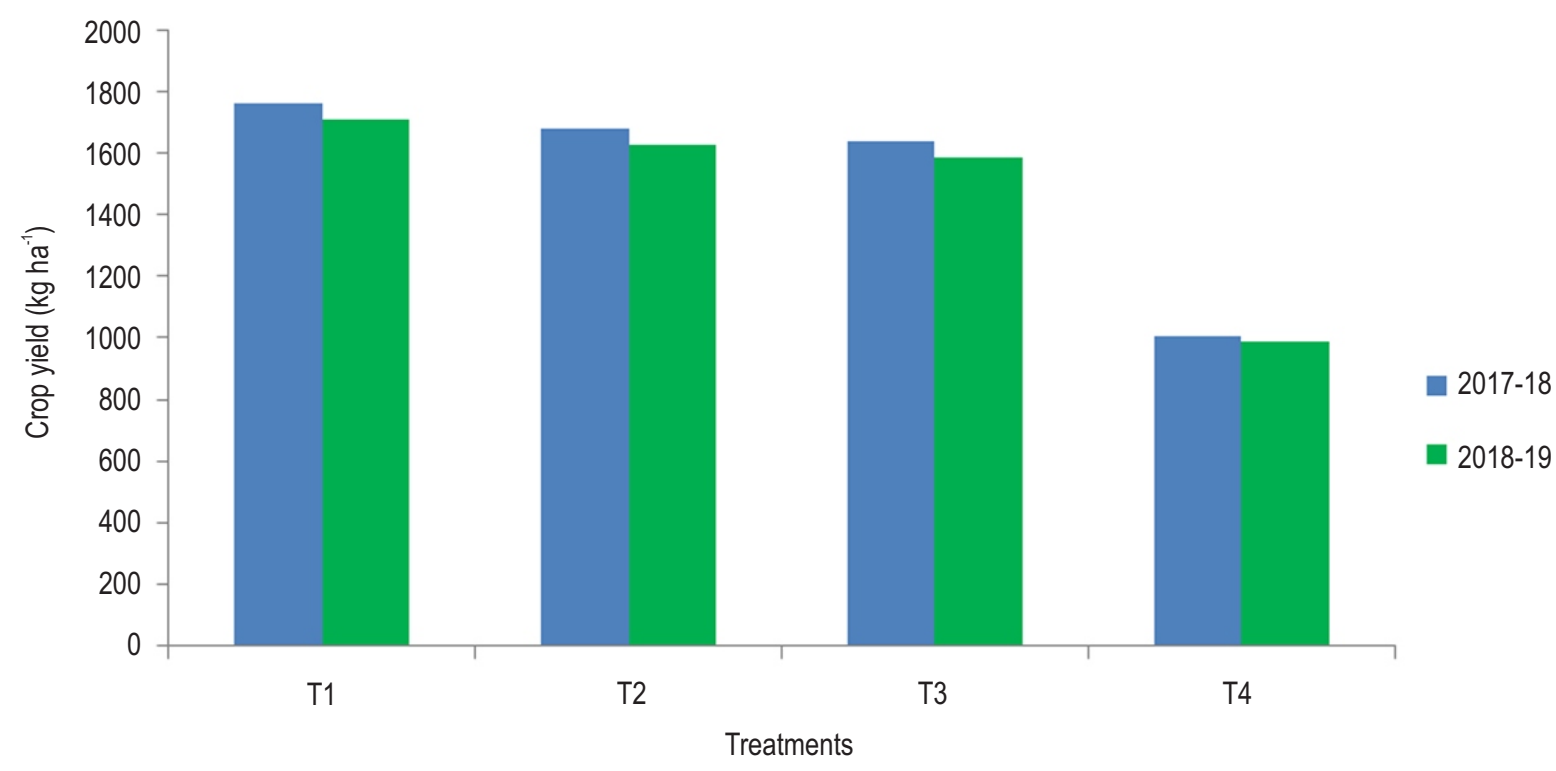

Fig. 1: Yield of sunflower influenced by irrigation at different MAD levels.

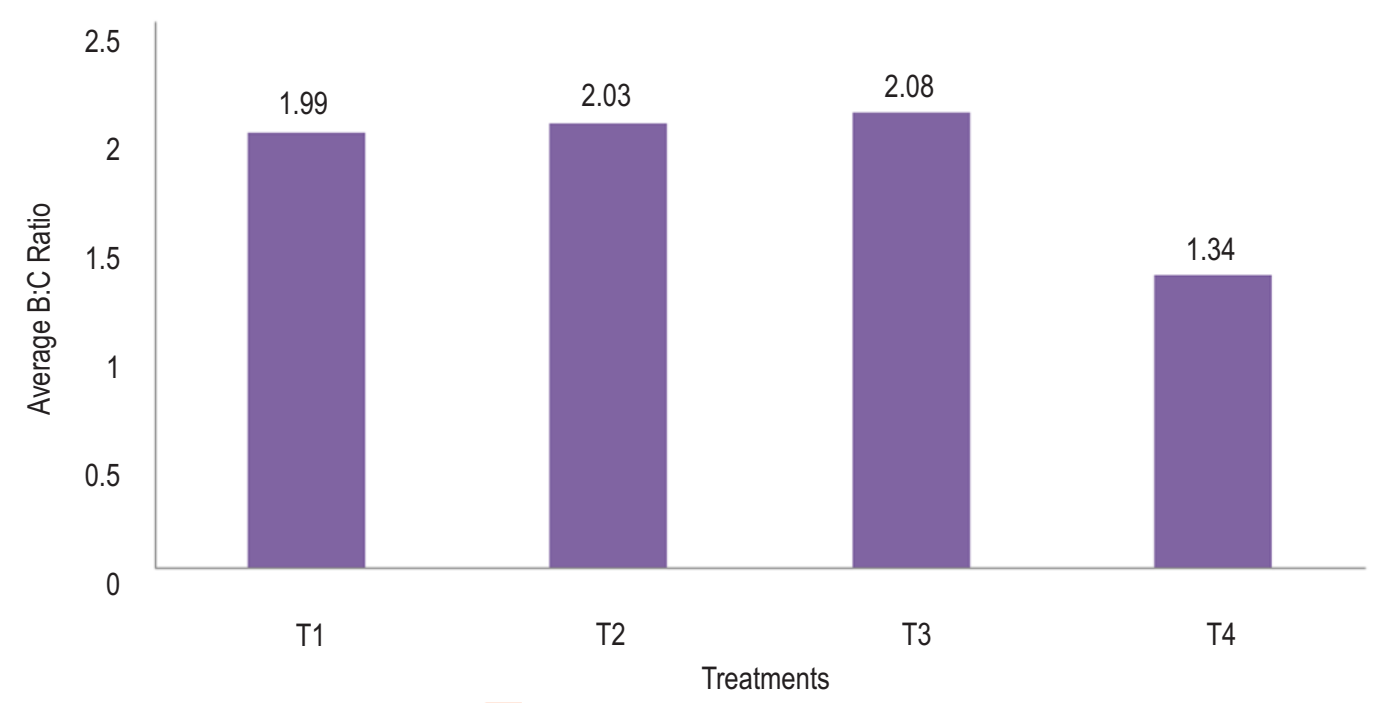

Fig. 2: Average B: $C$ value under different treatments for both years of experiment.

18and 2018-19, respectively. The average seed yield during both the years reduced by $4.64 \%$ and $7.03 \%$ when crop was irrigated at $40 \%$ and $60 \%$ of MAD. However, the yield drastically reduced by $42.5 \%$ when the crop was subjected to further moisture stress i.e. irrigation provided at $70 \%$ of MAD (Fig. 1). These results are in coincidence with the findings of Farshad et al. (2018) and Alahdadi (2011) who reported that superior seed yield of sunflower at full irrigation relative to limited irrigation due to higher protein synthesis under favourable moisture regime. Sher et al. (2018) also reported maximum yield of $1800 \mathrm{~kg} \mathrm{ha}^{-1}$ in sandy loam soil in Pakistan under furrow irrigation. The maximum yield obtained at $20 \%$ MAD level may be attributed due to maintenance of optimum soil moisture condition in the plant root zone which further resulted in balanced nutrient uptake and better plant growth (Marathe et al., 2018). Total water productivity and irrigation water productivity of sunflower is shown in Table 4 and 5 
for the experimental years 2017-18 and 2018-19, respectively. The highest TWP and IWP were observed in $60 \%$ MAD level, which ranged from 0.81 to $0.85 \mathrm{~kg} \mathrm{~m}^{-3}$ and 0.91 to $0.98 \mathrm{~kg} \mathrm{~m}^{-3}$, respectively, followed by $40 \%$ and $20 \%$ MAD level treatments. Both the water productivities showed that less than one $1 \mathrm{~kg}$ of sunflower can be produced effectively with 1 cubic meter or 1000 I of water in irrigated condition. It also depicts the virtual water requirement for sunflower production in eastern Indian conditions. The lowest water productivity was obtained in $70 \%$ MAD level, which might be attributed to drastic yield reduction relative to other treatments. Treatment irrigated at $60 \% \mathrm{MAD}$ level showed $83.4 \%$ increase in average Total water productivity and $74.4 \%$ increase in average irrigation water productivity as compared to farmers' practice during both the experimental seasons. As reported by Mila et al. (2017), the TWP and IWP of sunflower can reach up to 1.4 and $3.6 \mathrm{~kg} \mathrm{~m}^{-3}$, under control conditions, however, it depends on the potential yield of variety, availability adequate moisture at crop critical periods, proper plant spacing, weed control and disease pest management. The water productivity values obtained under the present investigation are similar to the average water productivity values of sunflower reported in earlier studies (Tolk and Howell, 2012; Lamm et al., 2011) which varied from $0.74-0.82 \mathrm{~kg} \mathrm{~m}^{-3}$.

Net economic water productivity (NEWP): It represents the economic benefits obtained by the farmers against investment for irrigation. The average value of net economic water productivity (NEWP) varied from 5.7 to $19.9 \mathrm{Rs} \mathrm{m}^{-3}$ (Table 6). The highest NEWP of $22.9 \mathrm{Rs} \mathrm{m}^{-3}$ was obtained in $60 \%$ MAD level. The NEWP of $40 \%$ and $20 \%$ MAD level was estimated to be 20.5 and $19.9 \mathrm{Rs} \mathrm{m}^{-3}$, respectively. The lowest NEWP of 5.7 Rs $\mathrm{m}^{-3}$ was recorded in farmers' practice due to significantly lower seed yield and its associated economic returns. The results depicted that with low investment in deficit irrigation, farmers can obtain higher economical benefits. Low application of irrigation under farmers' practice (70\% MAD) restricts the root growth and roots come to surface due to hard sub-soil that leads to low yield and ultimately low economic return. The experimental results confirm that there is scope to increase the economic water productivity of sunflower under controlled irrigation scheduling as compared to farmers' practice.

Proper irrigation scheduling is a critical factor for obtaining higher profit from sunflower cultivation. A comparison of net return per hectare showed that the increase in grain yield and reduction in cost of irrigation resulted in higher net return from MAD based irrigation experiments as compared to the farmers' practice. The net return in 20\% MAD level of irrigation was comparatively higher than other treatments. Which may be due to incremental yield obtained at optimum irrigation level with minimum moisture stress as compared to other treatments. However, the drastic reduction in seed yield of sunflower at $70 \%$ MAD level i.e., farmers' practice resulted in lowest net returns which was quite significant even compared to $60 \%$ MAD level. The average $B: C$ value of 2.08 was achieved in $60 \%$ MAD level treatment of the trials conducted during 2017-18 and 2018-19 and the lowest value (1.34) was recorded under farmers' practice as shown in Fig 2. This indicates that there was around $55 \%$ increase in B:C value in case of $60 \%$ MAD level when compared to farmers' practice. The analysis revealed that deficit irrigation at $60 \%$ MAD level gave the highest economic return per unit investment although it had some lower net return than $20 \%$ MAD level. Overall, the findings of the study revealed that growth, yield and water productivity of sunflower were significantly influenced by different irrigation levels. Irrigation scheduling at 20\% MAD level showed the highest grain yield, while the lowest yield was obtained from farmers' practice. This treatment would be beneficial for farmers if they have access to favorable moisture regime supported by water resource availability during rabi season in irrigation commands.

The reduction in seed yield of sunflower was not remarkable upto $60 \%$ MAD level compared to $20 \%$ MAD level, however it declined significantly at 70\% MAD level i.e. farmers' practice. Similarly, irrigation at $60 \%$ MAD level has shown the highest water productivity when compared to farmers' practice as it produced the highest yield per unit quantity of water application of $0.85 \mathrm{~kg} \mathrm{~m}^{-3}$ and also produced highest average benefit to cost ratio of 2.08. Most importantly, water saving under irrigation at $60 \%$ MAD level even saves 19\% of irrigation water as compared to conventional farmers' practice, and thus, it can be a better option for irrigation scheduling in sunflower for East and South eastern coastal plains of Odisha.

\section{Acknowledgment}

The authors are thankful to the ITRA water project funded by the Ministry of Electronics and Information Technology, Government of India, operating under the Department of Soil and Water Conservation Engineering, CAET, OUAT, Bhubaneswar for providing adequate support for successfully conducting the two year of field experiments.

\section{Add-on Information}

Authors' contribution: P.K. Sahu: Experimental work \& manuscript preparation, A.P. Sahu: Technical support for experiment \& manuscript preparation, P.S. Brahmanand, B. Panigrahi: Technical support for experiment \& manuscript preparation, Statistical Analysis, D.M. Das: Technical support for experiment \& manuscript preparation, B.C. Sahoo: Technical support for experiment , D.K. Swain: Statistical Analysis and Guidance.

Research content: The research content of manuscript is original and has not been published elsewhere.

\section{Ethical approval: Not applicable}

Conflict of interest: The authors declare that there is no conflict of interest. 
Data from other sources: Not applicable

Consent to publish: All authors agree to publish the paper in Journal of Environmental Biology.

\section{References}

Agricultural Research Data Book: Indian Council of Agriculture Research, Krishi Bhawan, New Delhi, pp. 211-219 (2018).

Alahdadi, I., H. Oraki and F.P. Khajani: Effect of water stress on yield and yield components of sunflower hybrids. Afri. J. of Biot., 10, 65046509 (2011).

Albaji, M., S.B. Nasab, A.A. Naseri and A. Shahnazari: Water productivity and water use efficiency of sunflower under conventional and limited irrigation. J. FoodAgri. Envi., 9, 202-209 (2011).

Awady, M.N.E., F.M.M. Altellawy, Y.F. Kishk, K.T. Albagoury and A.M.E. Sarraf: Drip irrigation effect on sunflower oil production in the sandy soil. J. Envi. Sci., 40, 65-94 (2017).

Bajehbaj, A.A.: Effects of water limitation on grain and oil yields of sunflower cultivars. J. Food, Agri. Envi., 8, 98-101 (2010).

Basa, A.G., V. Ion, D. Marin, T. Georgeta, D. Georgeta, L.I. Epure and S. Daniel: Above ground biomass of sunflower plants under different planting patterns and growing conditions. Sci. Papers. Series A. Agron., 57, 101-109 (2014).

Das, D.M., D.R. Mailapalli, A. Dalai and N. Kumar: A comparative study on water productivity of rice under different cultivation practices. $J$. Agril. Engg., 55, 66-73 (2018).

Elsheikh, E.R.A.: Water productivity of sunflower under different irrigation regimes on Gezira clay soils, Sudan, p. 168 (2015).

Farshad, N., J. Soodabeh, G. Mehdi and E. Ali: Studying the physiological and yield responses of sunflower inbred lines to full and limited irrigation. J. Integr. Agri., 17,1605-1611 (2018).

Flagella, Z., T. Rotunno, E. Tarantino, R.D. Caterina and A.D. Caro: Changes in seed yield and oil fatty acid composition of high oleic sunflower hybrids in relation to the sowing date and the water regime. Eur. J. Agron., 17, 221-230 (2002).

Garcia-Lopez, J., I.J. Lorite, R. Garcia-Ruiz, R. Ordonez and J. DominGuez: Yield response of sunflower to irrigation and fertilization under semi-arid conditions. Agri. WaterMang., 176,151-162 (2016).

Geerts, S. and D. Raes: Deficit irrigation as an on-farm strategy to maximize crop water productivity in dry areas. Agri. Water Mang., 96, 1275-1284 (2009).

Ghani, A., M. Hussain and M.S. Qureshi: Effect of different irrigation regimens on the growth and yield of sunflower. Int. J. Agri. Bio., 2, $334-335(2000)$.

Gholamhoseini, M., A. Ghalavand, A. Dolatabadian, E. Jhamshidi and A. Khodaei-Joghan: Effects of arbuscular mycorrhizal inoculation on growth, yield, nutrient uptake and irrigation water productivity of sunflowers grown under drought stress. Agri. Water Mang., 117, 106-114 (2013).

Gomez, K.A. and A.A. Gomez: Statistical Procedures for Agricultural Research. $2^{\text {nd }} E d n$. International Rice Research Institute, Wiley Inter Science Publication (John Wiley \& Sons), New York, pp. 20-30 (1984).

Haq, A., M.A. Rashid, M.A. Butt, M. Akhter Aslam and A. Saeed: Evaluation of sunflower (Helianthus annuus L.) hybrids for yield and yield components in central Punjab. J. Agri. Res., 44, 277-285 (2006).

Howell, T.A., S.R. Evett, J.A. Tolk, K.S. Copeland and T.H. Marek: Evapotranspiration, water productivity and crop coefficients for irrigated sunflower in the U.S. Southern high plains. Agri. Water Mang., 162, 33-46 (2015).
Jing, B., F. Shah, E. Xiao, J.A. Coulter and W. Wu: Sprinkler irrigation increases grain yield of sunflower without enhancing the risk of root lodging in a dry semi-humid region. Agri. Water Mang., 239, 106270 (2020).

Kaviya, V., N.K Sathyamoorthy, M. Rajeswari and C.R Chinnamuthu: Effect of deficit drip irrigation on water use efficiency, water productivity and yield of hybrid sunflower. Res. J. Agri. Sci., 9, 1119-1122 (2018).

Lamm, F.R., R.M. Alken and A.A. Abouldheira: Irrigation research with sunflowers in Kansas. Proceedings of the $23^{\text {rd }}$ Annual Central Plains Irrigation Conference, Burlington, Kansas, pp. 169-180 (2011).

Langeroodi, A.R.S., B. Kamkar, J.A.T. Silva and M. Ataei: Response of sunflower cultivars to deficit irrigation. Helia, 37, 37-58 (2014).

Li, W., H. Zhang, Y. Zeng, L. Xiang, Z. Lei, Q. Huang, T.L.F. Shen and Q. Cheng: A salt tolerance evaluation method for sunflower (Helianthus annuus I.) at the seed germination stage. Sci. Rep., 10, 1-9 (2020).

Marathe, R.A., K.D. Babu and D.T. Chaudhari: Nutrient uptake, growth and yield of pomegranate as influenced by irrigation frequencies under light textured soils. J. Envi. Bio., 39,143-148 (2018).

Mila, A.J., M.H. Ali, A.R. Akanda, M. Harun and M.A. Rahman: Effects of deficit irrigation on yield, water productivity and economic return of sunflower. Cog. Food Agri., 3, 128-135 (2017).

Nasim, W., A. Ahmad, A. Bano, M. Usman, R. Olatinwo, H.M. Hammad, T. Khaliq and M. Hussain: Effect of nitrogen on yield and oil quality of sunflower (Helianthus annuus L.) hybrids under sub humid conditions of Pakistan. Am. J. Plant Sci., 3, 243-251 (2012).

National Mission on Oilseeds and Oil Palm (NMOOP), Ministry of Agriculture and Farmers Welfare, Government of India. https:// nmoop. gov.in/Introduction.aspx.

Panigrahi, B.: A Handbook on Irrigation and Drainage. $1^{\text {st }}$ Edn., New India Publishing Agency, New Delhi, 620 p. (2013).

Panigrahi, B: Irrigation Systems Engineering. $1^{\text {st }}$ Edn., New India Publishing Agency, New Delhi, 345 p. (2011).

Panigrahi, B., S.D. Sharma and B.P. Behera: Irrigation water requirement models of some major crops. Water Res. Mang., 6, 69-77 (1992).

Qureshi, A.L., M.A. Gadehi, A.A. Mahessar, N.A. Memon, A.G. Soomro and A.H. Memon: Effect of drip and furrow irrigation systems on sunflower yield and water use efficiency in dry area of Pakistan. Am. Eur. J. Agri. Env. Sci., 15, 1947-1952 (2015).

Sher, A., M. Suleman, A. Qayyum, A. Sattar, A. Wasaya, M. ljaz and A. Nawaz: Ridge sowing of sunflower in a minimum till system improves the productivity, oil content and profitability on a sandy loam soil under an arid climate. Env. Sci. Pol. Res., 10,134-136 (2018).

Singh, C.B., M.S. Bhullar and C.J.S. Singh: Response of sunflower to furrow irrigation in arid region of Northern India. An. Asian J. Soil Sci., 2, 108-112 (2007).

Singh, D.K. and A.K. Singh: Groundwater and situation in India: Problems and perspective. Int. J. Water Res. Dev., 18, 563-580 (2002).

Tolk, J.A. and T.A. Howell: Sunflower water productivity in four great plains soils. Field Crop Res., 127, 120-128 (2012).

Vega, A.J. and A.J. Hall: Effects of planting date, genotype, and their interactions on sunflower yield: I. determinants of oil-corrected grain yield. Crop Sci., 42, 1191-1201 (2002).

Vladimir P.V., M.C. Evgeniy, A.A. Mostyakova and A.A. Ilgamov: Sunflower productivity and gross oil production on the grey forest soil of the republic of Tatarstan under the use of growth regulators. Bio. Web Conf., 17, 1-5 (2020).

Wahba, S.A., S.I.A. Rahman, M.Y. Tayel and M. Matyn: Soil moisture, salinity, water use efficiency and sunflower growth as influenced by irrigation, bitumen mulch and plant density. Soil Tech., 3, 33-44 (1990). 